\title{
Does Board Behaviour Matter for Board Effectiveness in Small and Medium Industries (SMEs)?: A Preliminary Observation
}

\author{
Nazir Adi ${ }^{*}(\mathbb{D})$, Arifha Mohamad ${ }^{2}$ (D), Wan Fauziah Wan Yusoff 3 (iD) \\ 1Department of Business Management, Faculty of Technology Management and Business, Universiti Tun \\ Hussein Onn Malaysia (UTHM), 86400, Batu Pahat, Johor, Malaysia. \\ Email: nazir@uthm.edu.my \\ 2Department of Business Management, Faculty of Technology Management and Business, Universiti Tun \\ Hussein Onn Malaysia (UTHM), 86400, Batu Pahat, Johor, Malaysia. \\ Email: arifha@uthm.edu.my \\ ${ }^{3}$ Department of Business Management, Faculty of Technology Management and Business, Universiti Tun \\ Hussein Onn Malaysia (UTHM), 86400, Batu Pahat, Johor, Malaysia. \\ Email: fauziahy@uthm.edu.my
}

\section{CORRESPONDING \\ AUTHOR (*): \\ Nazir Adi \\ (nazir@uthm.edu.my) \\ KEYWORDS: \\ Corporate governance \\ Board behaviour \\ Small and medium-sized \\ enterprises}

\section{CITATION:}

Nazir Adi, Arifha Mohamad \& Wan Fauziah Wan Yusoff. (2022). Does Board Behaviour Matter for Board Effectiveness in Small and Medium Industries (SMEs)?: A Preliminary

Observation. Malaysian Journal of Social

Sciences and Humanities (MJSSH), 7(2),

e001276.

https://doi.org/10.47405/mjssh.v7i2.1276

\begin{abstract}
The issue of corporate governance affects big corporations and small businesses. Maintaining a well-functioning board of directors in small and medium-sized enterprises (SMEs) is one of the most effective ways of increasing the efficacy of the board. This article examines previous studies on board behaviour that are critical to the effectiveness of boards of directors in small and medium-sized enterprises (SMEs). Previous literature found several attributes of directors that need to be nurtured. Having a different view relating to the task in a boardroom, preparedness, involvement, use of specific knowledge and skills are among them. In short, more empirical studies relating to these antecedents are recommended to understand board behaviour better, especially when making a decision.
\end{abstract}

Contribution/Originality: This study contributes to the existing literature by identifying three crucial board-process antecedents that may affect board effectiveness. Those antecedents are task conflict, effort norms, and the use of knowledge. We recommend future research to explore these antecedents using another alternative method, such as a qualitative approach.

\section{Introduction}

Corporate scandals and failures have led to the downfall of countless corporations around the world. The failures of Enron and WorldCom in the United States (US) drew the government's attention to enforcing the Sarbanes-Oxley Act in 2002. Similarly, Baring Bank and Royal Bank of Scotland (RBS) failures are typical examples of business failures in the United Kingdom (UK). It justifies the British government taking preventive actions, such as 
passing the UK Corporate Governance Code (Mallin, 2013). The Code stemmed from the consolidation and harmonisation of preceding reports.

The problem of the board directors is a long-standing concern in the business environment. In Malaysia, the board that violates corporate governance practices is recorded in statistics issued by the Companies Commission of Malaysia (CCM). Figure 1 illustrates the number of investigations affecting directors issued by the CCM. It shows that cases involving directors who were reported to violate the laws were consistently high from 2017 to 2019. Most of these cases involved small companies and businesses such as private limited companies, partnerships, sole proprietorship and limited liability partnerships.

Figure1: Number of Investigations Affecting Directors

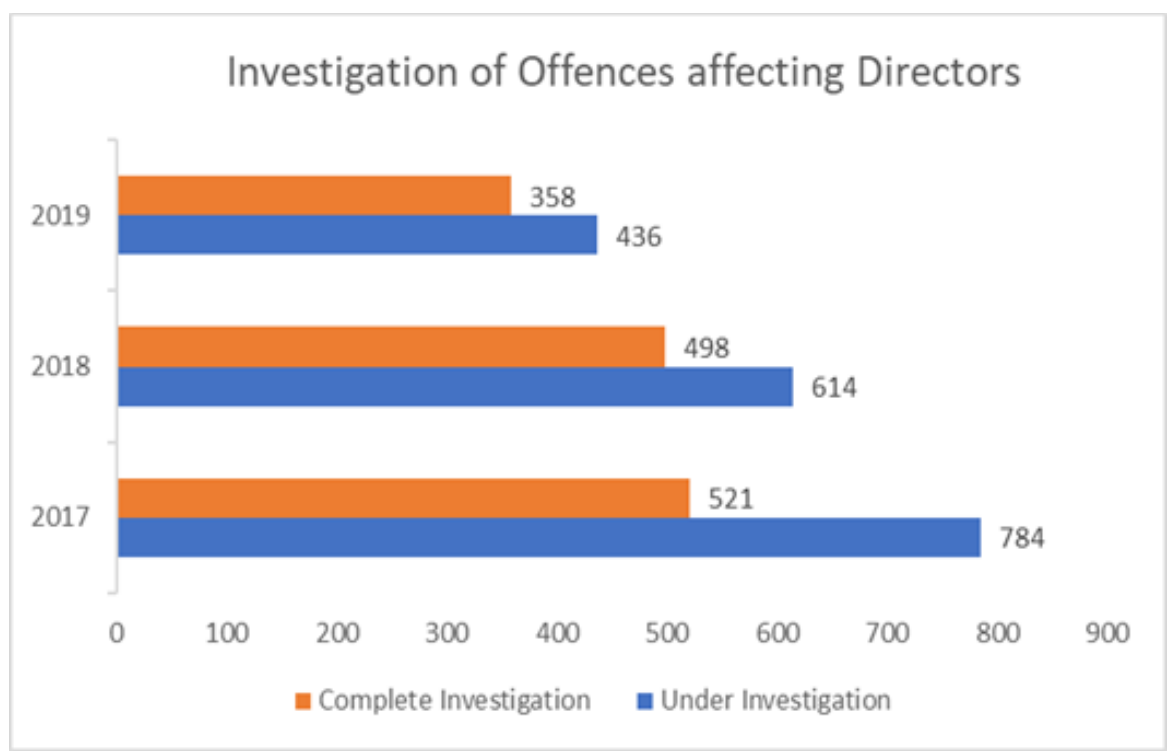

Source: Companies Commission of Malaysia Annual Report (2019)

In addition, the number of business entities investigated in 2019 in which the majority affected SMEs compared to public companies is shown in Figure 2.

Figure 2: Business Entities Involved in the Investigation in 2019

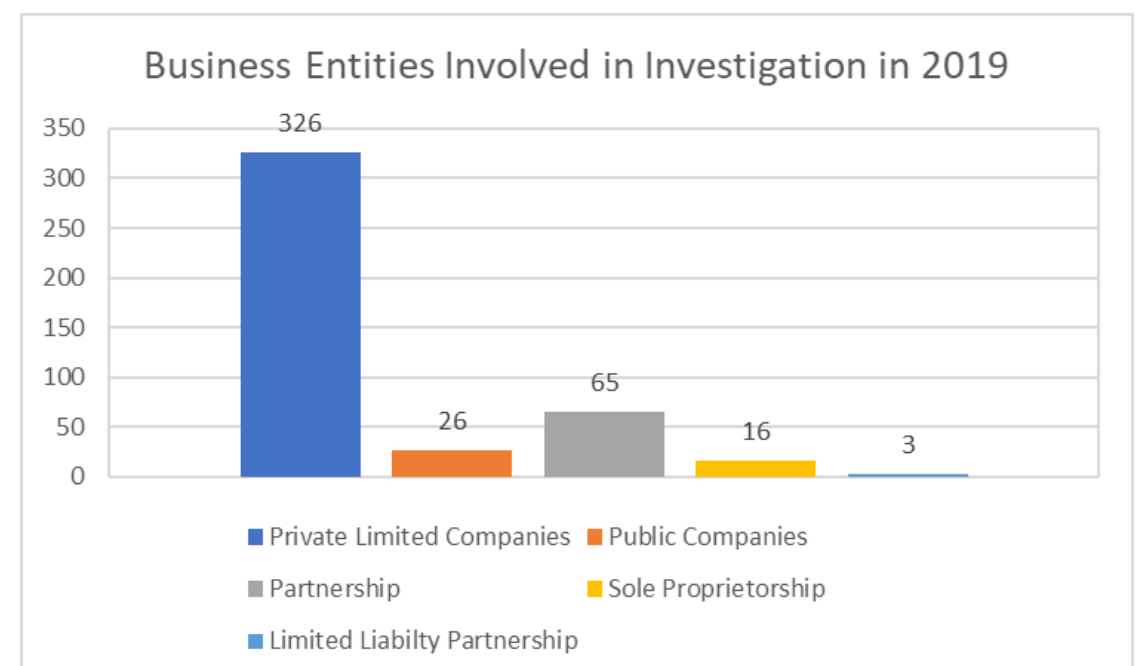

Source: Companies Commission of Malaysia Annual Report (2019) 
The following is the structure of this article: first, we begin with a review of the literature that provides context for the preceding investigations. Following that, the methodology used, the results, and a discussion of the findings are presented. Finally, towards the conclusion of the article, we make a final observation.

\section{Literature Review}

The majority of research on board effectiveness applied the traditional approach when assessing board performance. Invariably, the board structure and composition were tested directly linked with board performance. However, some authors believed that more important or significant is investigating the phenomenon inside the boardroom (Minichilli et al., 2009; van Ees, van der Laan, \& Postma, 2008). A recent study has learned that board processes become determinant factors on board effectiveness (Jansen \& Raita, 2021). It is also worthy to note that boards with certain valued cultures such as the decision-making process, critical questioning, cohesiveness, and others can create innovation (Jaskyte, 2018). The following sections unfold several antecedents that the previous studies have investigated.

\subsection{Cognitive Conflict}

Studies showed that cognitive or task conflict arises when a board reaches a certain degree of disagreement to perform the duties and adopt the best strategy towards the decision (Babic, Nikolic, \& Eric, 2011; Obgbechie, 2012; Wirtz, 2011). A study conducted by BarrosoCastro, Villegas-Periñan, and Dominguez (2017) perceived task conflict as a form of conduct in which board members have diverse outlooks and preferences or methods resolving an issue or making a judgement. In a similar vein, Kerwin et al. (2011) asserted that task conflict was a constructive occurrence despite its intensity among the board. Also, Amason (1996) impliedly concerned about the risk of cognitive conflict towards the decision quality since there is collinearity between cognitive conflict and affective conflict. In other words, though cognitive conflicts were positively associated with the higher-quality decision, it would decrease by the presence of the effective conflict (Amason, 1996).

Nevertheless, if task conflict goes beyond the control and becomes more personal, it would undermine the quality of the decision (Kerwin et al., 2011), which indirectly exacerbates board task performance (Heemskerk et al., 2017). Accordingly, those members of the board who are capable of inhibiting task conflict into relationship conflict perform better than the others (Eisenhardt, Kahwajy, \& Bourgeois, 1997; Ensley, Pearson, \& Amason, 2002). In line with these findings, Kerwin et al. (2011) developed a model of specific conditions that influence not only the intensity of cognitive conflict but also affective and process conflict as illustrated in Figure 3.

In their meta-analysis, contrariwise, De Dreu and Weingart (2003) found a contradictory outcome that the effect of cognitive conflict towards group or firm is just likely as the affective conflict, which is, dysfunctional effect. Likewise, meta-analysis findings from several authors revealed that task conflicts exerted null relations with team performance and team innovation (Bradley et al., 2015; de Wit et al., 2012; 0’Neill, Allen, and Hastings, 2013). However, the finding turned out to be more intriguing when they suggested that task conflict may positively affect team performance when relationship conflict is low (de Wit et al., 2012). In other words, not all task conflicts benefit team performance. There are some exceptional occurrences or moderating factors in which those tasks bring about conflict yet 
lead to high performance. For instance, task conflicts are beneficial for performance when the tasks at hand are complex to be decided by the team (O'Neill et al., 2013).

Figure 3: A model of the conditions that influence the intensity of task, process, and relationship conflict

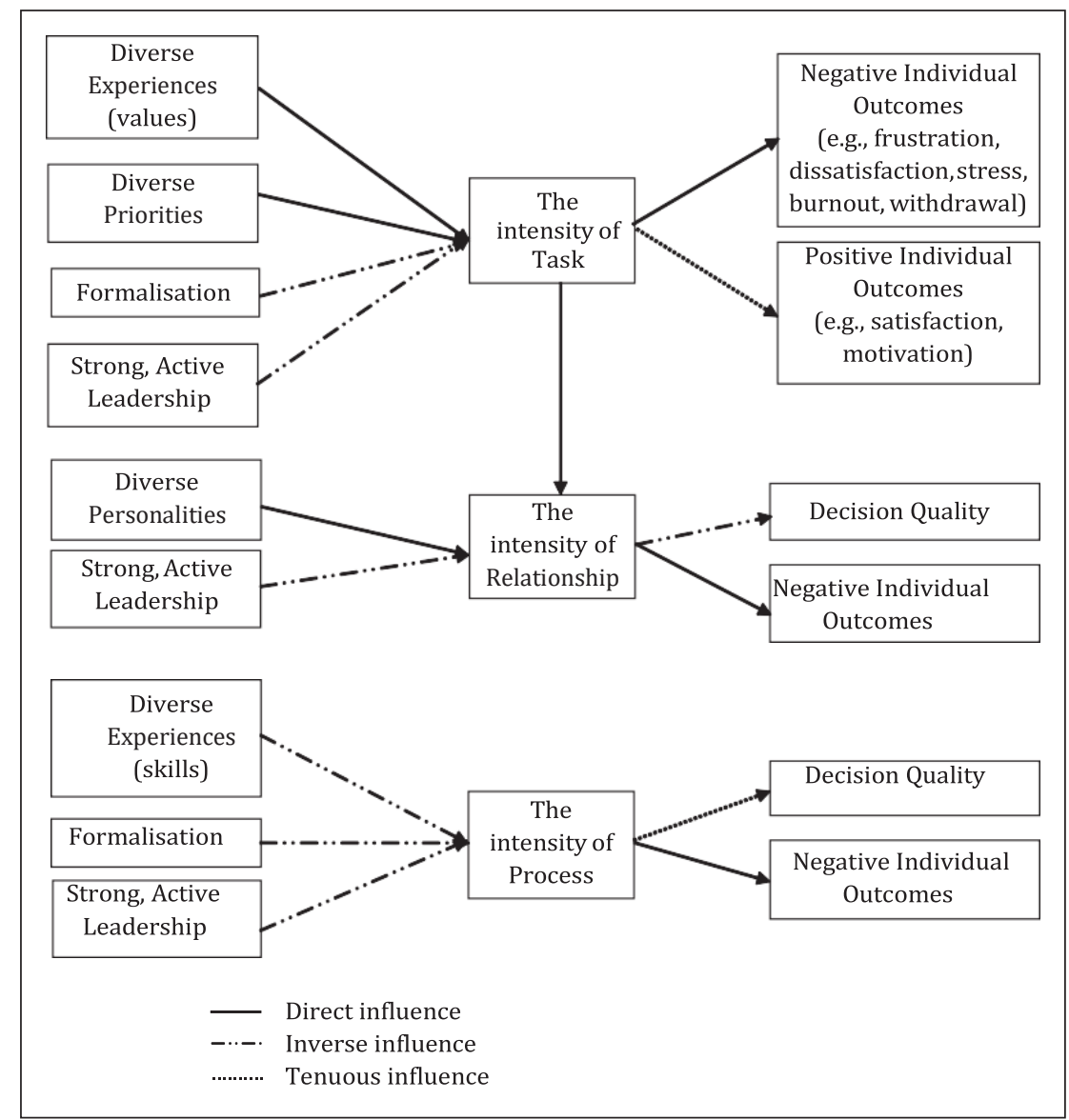

Source: Adopted from Kerwin et al. (2011)

\subsection{Effort Norms}

Effort norms can be illuminated by several examples, as noted by Wan and Ong (2005), as the practice of issuing meeting agendas within a reasonable time before the meeting. The rationale is that it gives ample time for the directors to be prepared with agendas to be debated prior to the meeting. Ultimately, directors may have lots of opportunities to deliberate the company's strategic plan and monitor the company's performance. Specifically, Wan and Ong (2005) employed five items to measure general effort norms: check the information thoroughly, participate actively in board meetings, enjoy work, feel responsible for work, and be satisfied when work is accomplished well. Wageman (1995) gave specific illustrations for the researcher who wishes to research the realm of effort norms such as "taking notes during meetings" or "participating actively during meetings," "carefully" scrutinising the information provided by the firm before meetings," and "researching issues relevant to the company." Some authors suggested that certain board members must possess related knowledge and skills in running a company, for example, in a firm specific-knowledge such as finance, marketing, and accounting (Zattoni et al., 2012). Maharaj (2009) expressly recommended that board members be knowledgeable regarding financial matters to be ready to debate any issues affecting financial performance in the board meeting. 


\subsection{Use of Knowledge and Skills}

Several authors found that the use of knowledge and skills influences board role performance (Forbes \& Milliken, 1999; Huse, 2005; Zona \& Zattoni, 2007; van Ees, van der Laan, \& Postma, 2008; Babic et al., 2011). As a matter of fact, firm performance is highly anticipated from using knowledge and skills rather than lessening agency cost (Ees et al., 2009). It is also suggested that the level of knowledge and expertise would be related to the level of monitoring of the top management and performance (Roy, 2009). Further, Zattoni et al. (2012) concurred with the finding made by Forbes and Milliken (1999) that apart from other board processes like effort norms and cognitive conflict, the effectiveness of board directors is strongly influenced by the emergence and use of knowledge and skills. They found that family involvement has a positive influence on knowledge and skills.

With regard to the measures employed to gauge the use of knowledge and skills, past studies showed various items. Most of the previous studies appreciated the tools developed by Forbes and Milliken (1999) in assessing the use of knowledge and skills among board members. In this respect, Forbes and Milliken (1999) differentiate the term presence of knowledge and the use of knowledge on the assumption that though the knowledge is present among the board members, it is not necessarily being leveraged effectively. Hence, a study can describe the knowledge and skills into two main dimensions: (1) Critical area knowledge and skills and (2) firm-specific knowledge and skills. While, in terms of the use of knowledge, a study may ask the board members (1) whether they are conscious about the others' expertise, (2) the influence of the most knowledgeable members in a particular issue, and (3) task delegation is equilibrium with the knowledge and responsibilities. In addition, by referring to McGrath and MacMillan (1995) and Forbes and Milliken (1999), they suggest additional questions like (1) denial to accept important information (reverse coded) and (2) information pours smoothly among members of the board. This measurement has been adopted along the same vein by Zona and Zattoni (2007) and Zattoni et al. (2012).

Machold et al. (2011) took a different scale when measuring board members' knowledge by constructing a four-items adopted from Minichilli and Hansen (2007). Those questions were (1) the activities of the main business purposes; (2) the firm's critical technologies and key competencies; (3) the firm's products and services; and (4) the progress of the firm's markets and customer needs. Obgbechie (2012) listed down several items to assess the use of knowledge and skills such as (1) Knowledge of industry, (2) Understanding of the business of your firm, (3) Understanding of the industry in which your firm operates (4) Knowledge about financial matters (5) Knowledge about legal matters and (6) Knowledge about risk matters.

\section{Discussion}

Several types of directors' behaviour can be inferred from the above literature. For instance, cognitive or task conflict has been an important attribute among directors. This task may be practised in debate or a different opinion that invariably ensued in the boardroom. The benefits of such diverse views can lead to a positive outcome for the director, such as diverse experience and priorities (Kerwin et al., 2011). However, the positive conflict may have some limitations. An exaggerated conflict may bring about adverse effects on directors and decision qualities. Likewise, the directors are expected to be prepared and participate in the decision-making. Such preparation shows that directors are ready to give factual opinions that may shape the quality of the decision. For instance, directors need to participate in the decision-making process in the board meeting. 
In terms of the use of knowledge and skills, directors are assumed to have some basic knowledge and skills to apply, especially when making decisions. With the digital and technological advancement, a director is demanded to have this technical knowledge. Besides, the director must have basic knowledge of the nature in which the firm or company is ventured or rather called firm-specific knowledge. Such related knowledge and skill can enhance the competitive advantage of the company.

\section{Conclusion}

We discovered various types of director behaviour that, when combined, might increase the effectiveness of a board. To summarise, cognitive conflict, effort norms (preparedness and involvement), and the use of knowledge are all crucial for achieving this goal on the board of directors. It is recommended that boards of directors be instilled with these values as they carry out their responsibilities. More empirical studies are needed to have an insight into board behaviour in SMEs. It is hoped that this research would contribute to establishing a framework for good board behaviour in the future. The framework can then be translated into tools and inventories that can be used to assess the effectiveness of a director's performance.

\section{Acknowledgement}

Part of this article was extracted from a doctoral thesis submitted to Universiti Tun Hussein Onn Malaysia

\section{Funding}

This research was supported by Universiti Tun Hussein Onn Malaysia (UTHM) through Tier 1(Vot H779).

\section{Conflict of Interests}

The authors declare no conflict of interest in this study.

\section{References}

Amason, A. C. (1996). Distinguishing the Effects of Functional and Dysfunctional Conflict on Strategic Decision Making: Resolving a Paradox for Top Management Teams. The Academy of Management Journal, 39(1), 123-148. https://doi.org/10.2307/256633

Babic, V. M., Nikolic, J. D., \& Eric, J. M. (2011). Rethinking board role performance: Towards an integrative model. Economic Annals, 56(190), 140-162. https://doi.org/10.2298/EKA1190140B

Barroso-Castro, C., Villegas-Periñan, M. M., \& Dominguez, M. (2017). Board members' contribution to strategy: The mediating role of board internal processes. European Research on Management and Business Economics, 23(2), 82-89. https://doi.org/10.1016/j.iedeen.2017.01.002

Bradley, B. H., Anderson, H. J., Baur, J. E., \& Klotz, A. C. (2015). When conflict helps: Integrating evidence for beneficial conflict in groups and teams under three perspectives. Group Dynamics: Theory, Research, and Practice, 19(4), 243-272. 
https://doi.org/10.1037/gdn0000033

Companies Commission of Malaysia Annual Report (2019)., https://www.ssm.com.my/bm/Pages/Publication/Annual_Report/AnnualReport.aspx

De Dreu, C. K. W., \& Weingart, L. R. (2003). Task versus relationship conflict, team performance, and team member satisfaction: A meta-analysis. Journal of Applied Psychology, 88(4), 741-749. https://doi.org/10.1037/0021-9010.88.4.741

de Wit, F. R. C., Greer, L. L., \& Jehn, K. A. (2012). The paradox of intragroup conflict: A metaanalysis. Journal of Applied Psychology, 97(2), 360-390. https://doi.org/10.1037/a0024844

Ees, H. Van, Gabrielsson, J., \& Huse, M. (2009). Toward a Behavioral Theory of Boards and Corporate Governance STUDY OF BOARDS AND CORPORATE. Corporate Governance: An International Review, 17(3), 307-319. https://doi.org/10.1111/j.14678683.2009.00741.x

Eisenhardt, K. M., Kahwajy, J. L., \& Bourgeois, L. J. (1997). How Management Teams Can Have a Good Fight How Management Teams Can Have a Good Fight. Harvard Business Review, 75(4), 77-86.

Ensley, M. D., Pearson, A. W., \& Amason, A. C. (2002). Understanding the dynamics of new venture top management teams: Cohesion, conflict, and new venture performance. Journal of Business Venturing, 17(4), 365-386. https://doi.org/10.1016/S08839026(00)00065-3

Forbes, D. P., \& Milliken, F. J. . (1999). Cognition and Corporate Governane ; Understanding Boards Directors As Strategic Decision-Making Group. Academic of Management Review, 24(3), 489-505.

Heemskerk, E. M., Heemskerk, K., \& Wats, M. M. (2017). Conflict in the boardroom: a participant observation study of supervisory board dynamics. Journal of Management and Governance, 21(1), 233-263. https://doi.org/10.1007/s10997-015-9339-8

Huse, M. (2005). Accountability and creating accountability: A framework for exploring behavioural perspectives of corporate governance. British Journal of Management, 16(SPEC. ISS.). https://doi.org/10.1111/j.1467-8551.2005.00448.x

Jansen, P., \& Raita, G. V. (2021). Macro-Level Determinants of Board Effectiveness in UK and Romanian Listed Companies: A Conceptual Approach. CECCAR Business Review, 2(10), 60-72. https://doi.org/10.37945/cbr.2021.10.08

Jaskyte, K. (2018). Board Attributes and Processes, Board Effectiveness, and Organizational Innovation: Evidence from Nonprofit Organizations. Voluntas, 1-14. https://doi.org/10.1007/s11266-017-9945-y

Kerwin, S., Doherty, A., \& Harman, A. (2011). "It's Not Conflict, It's Differences of Opinion." Small Group Research, 42(5), 562-594. https://doi.org/10.1177/1046496411398395

Machold, S., Huse, M., Minichilli, A., \& Nordqvist, M. (2011). Board leadership and strategy involvement in small firms: A team production approach. Corporate Governance, 19(4), 368-383. https://doi.org/10.1111/j.1467-8683.2011.00852.x

Maharaj, R. (2009). Corporate governance decision-making model: How to nominate skilled board members, by addressing the formal and informal systems. International Journal of Disclosure and Governance, 6(2), 106-126. https://doi.org/10.1057/jdg.2008.27

Mallin, C. A. (2013). Corporate Governance (4th edition, Vol. 1). Oxford University Press. https://doi.org/10.1017/CB09781107415324.004

McGrath, R. G., \& MacMillan, I. C. (1995). Defining and Developing Competence: A Strategic Process Paradigm. Strategic Managemenet Journal, 16(July 1994), 251-275.

Minichilli, A., \& Hansen, C. (2007). The board advisory tasks in small firms and the event of crises. Journal of Management and Governance, 11(1), 5-22. https://doi.org/10.1007/s10997-007-9014-9 
O'Neill, T. A., Allen, N. J., \& Hastings, S. E. (2013). Examining the "Pros" and "Cons" of Team Conflict: A Team-Level Meta-Analysis of Task, Relationship, and Process Conflict. Human Performance, 26(3), 236-260. https://doi.org/10.1080/08959285.2013.795573

Obgbechie, C. I. (2012). Key Determinants of Effective Boards of Directors - Evidence From Nigeria (Issue September). Brunel University.

Roy, M. J. (2009). Linking board types to key board roles. International Journal of Business Governance and Ethics, 4(3), 298. https://doi.org/10.1504/IJBGE.2009.023334

van Ees, H., van der Laan, G., \& Postma, T. J. B. M. (2008). Effective board behavior in The Netherlands. European Management Journal, 26(2), 84-93. https://doi.org/10.1016/j.emj.2008.01.002

Wageman, R. (1995). Interdependence and Group Effectiveness. Administrative Science Quarterly, 40(1), 145-180. https://doi.org/10.2307/2393703

Wan, D., \& Ong, C. H. (2005). Board structure, process and performance: Evidence from publiclisted companies in Singapore. Corporate Governance, 13(2), 277-290. https://doi.org/10.1111/j.1467-8683.2005.00422.x

Wirtz, P. (2011). The cognitive dimension of corporate governance in fast growing entrepreneurial firms. European Management Journal, 29(6), 431-447. https://doi.org/10.1016/j.emj.2011.06.004

Zattoni, A., Gnan, L., \& Huse, M. (2012). Does Family Involvement Influence Firm Performance? Exploring the Mediating Effects of Board Processes and Tasks. Journal of Management, 41(4), 1214-1243. https://doi.org/10.1177/0149206312463936

Zona, F., \& Zattoni, A. (2007). Beyond the black box of demography: Board processes and task effectiveness within Italian firms. Corporate Governance, 15(5), 852-864. https://doi.org/10.1111/j.1467-8683.2007.00606.x 